\title{
The Effect of Human Resource Management Practices on Organizational Commitment in Chain Pharmacies in Jordan
}

\author{
Haneen Bisharat ${ }^{1}$, Bader Yousef Obeidat ${ }^{1}$, Ala'aldin Alrowwad ${ }^{2}$, Ali Tarhini ${ }^{3} \&$ Ibrahim Mukattash $^{4}$ \\ ${ }^{1}$ Department of Business Management, The University of Jordan, Amman, Jordan \\ ${ }^{2}$ Department of Business Management, The University of Jordan, Aqaba, Jordan \\ ${ }^{3}$ College of Economics and Political Science, Department of Information Systems, Sultan Qaboos University, \\ Muscat, Sultanate of Oman \\ ${ }^{4}$ Department of Marketing, Faculty of Economics \& Administrative Studies, Applied Science University, Jordan \\ Correspondence: Ali Tarhini, College of Economics and Political Science, Department of Information Systems, \\ Sultan Qaboos University, Muscat, Sultanate of Oman. Tel: 974-5012-1922. E-mail: alitarhini@squ.edu.om
}

Received: November 14, 2016

Accepted: December 20, 2016 Online Published: December 28, 2016

doi:10.5539/ijbm.v12n1p50

URL: http://dx.doi.org/10.5539/ijbm.v12n1p50

\begin{abstract}
This study investigated the impact of Human Resource Management (HRM) practices on organizational commitment among pharmacists working in chain pharmacies in Jordan. The study was conducted across pharmacists of different levels in two chain pharmacies in Jordan. A questionnaire was designed and distributed to pharmacist working in two chain pharmacies in Jordan. Results found that training and development and reward system were positively and significantly impacted affective commitment; as well as both recruitment and selection and reward system were positively and significantly affected continuance commitment. However, no significant impact found between normative commitment and any of the suggested human recourse management practices. The results showed that the majority of the variables confirmed previous studies and the remaining minority did not support these studies due to factors such as culture, values, and the nature of health care practice. The results have a great implication for the pharmacy business sector in Jordan.
\end{abstract}

Keywords: human resource management practices, HRM, organizational commitment, chain pharmacy, Jordan

\section{Introduction}

The current business environment is characterized by dense uncertainty, instability, as well as radical change in the presentation of various challenges (Masa'deh et al., 2015, Orozco et al., 2015). Increased globalization, tremendous technological revolution (Shannak et al., 2010; Masa'deh, 2013), and the rapid growth of the need for qualified employees and improvement of performance are some of the environmental factors affecting the operation of organizations (Masa'deh et al., 2016; Obeidat et al., 2016). It is for this reason that organizations stretch to its limits to utilize the resources at their disposal so as to gain a competitive advantage in such environment (Al-Azmi et al., 2012; Alshurideh et al., 2012; Altamony et al., 2016; Almajali et al. 2016), exploiting their knowledge management systems (Kanaan et al., 2013; El-Masri et al., 2015; Masa'deh et al., 2017) and encouraging exceptional customer services and innovation practices (Hajir et al., 2015; Obeidat et al., 2016).

Human resources are among the most valuable assets that organizations can ever have to work towards achieving a competitive advantage. Othman (2009) argues that organizations can overcome the challenges that they face by using human resources in strategic manner. Therefore, it goes without saying that organizations have a huge role to play in managing the human resources they have. Different practices are essential in the management of human resources; such practices aim at creating and sustaining performance desired by the organizations as they are influential in determining the attitudes and employees' behavior (Armstrong, 2013). Furthermore, organizations look forward to developing a committed workforce as well as retaining their employees. The behavior of an organization can be improved by working on such areas as the commitment of staff members, their competency as well as the organization's human resource management flexibility.

Studies suggest that human resource management practices have a significant role to play in determining the commitment of employees (Alkalha et al, 2012; Vratskikh et al., 2016). Such practices are: selection, recruitment, 
training and development, appraisal of performance, development of teamwork, as well as compensation and reward. This research, therefore, focuses at investigating the possible relationship existing between the practice of human resource management and the commitment of the pharmaceutical organizations in Jordan (Alrowwad et al., 2017). The research also aims at establishing bridges in the gap between human resource practices and the employees' commitment in working towards achieving the goals and objectives of pharmaceutical firms in Jordan. To the best of the authors' knowledge, there are no previous studies that examine the relationship between the practice of human resource management and the commitment of the pharmaceutical organizations in Jordan. Hence, the application of this study is at a very important sector in Jordan in terms of its contribution to GDP and employment.

The rest of the paper is organized as follows: the next section reviews the relevant literature and previous studies related to the study. Section 3 explains the methodology used in conducting this study. Section 4 proposes the theoretical framework. It is then followed by analyzing the collected data in section 5. Finally, section 6 represents the findings of this research followed by limitations and recommendations for future research.

\section{Literature Review}

This section will discuss the literature related to human resource management practices and organizational commitment and their relationship with one another.

\subsection{Human Resource Practices}

Human resource practices can be defined as efforts marshaled by organizations in ensuring proper management of its pool as a way of targeting the achievement of organizational goals (Amstrong, 2013). Organizations employ such practices to form attitudes, behaviors, culture as well as perception of employees in such a way that it achieves the organizational desired outcomes (Shannak et al., 2012; Al-Sarayrah et al., 2016). Different human resource practices are applicable to different organizations (Blumberg et al, 2005). In this case, the practices have been grouped into four major categories such as the methods of recruiting, training and development, the reward systems, and appraisals of employee performance.

\subsubsection{Recruitment Methods}

An organization's success exclusively depends on its employees. Therefore, organizations must recognize searching for the best employees during its recruitment process as a necessary action (Solomon, 2013). In order to ensure that it produces the best employees' possible, recruitment, which is a staffing activity, demands abstemious and elaborates organizational methods. The major reason for recruitment is to satisfy an organization's craving for highly qualified candidates to fill out openings within its establishment. The methods of recruitment are specific ways of developing the different stages of the recruitment process, which ranges from sourcing candidates to making a hiring decision. Furthermore, methods and practices should be added to the detailed recruitment best practices document or policy framework so as to optimize each stage for conversion and cost effectiveness (Taylor, 2014).

There are three basic steps that form the recruitment process, namely resume selection, testing (written or oral), and interviewing. Each kind of job demands that applicants possess a basic qualification. This qualification may be as a result of education or experience or as a result of both. The human resource personnel select resumes that meet the basic requirements of the job position for which it was submitted. In some cases, references attesting applicants' professional experiences are required. Therefore, references are a way for organizations to confirm the genuineness of provided information (Council, 2013).

The foremost qualified applicants are selected for the next step, which is testing. These tests can be knowledge-based, medical, personality-based, or simply achievement tests. In some cases, the candidate is requested to undergo a number of tests. To assess a candidate's necessary-knowledge reservoir, knowledge-based tests are administered, and hence crucial. This test assesses a person's attitude, general awareness, reasoning capability, and, more critically, memory capacity (Council, 2013). The interview is the final step in the recruitment process, which is followed by an actual job offer and a salary negotiation. For an interview to be well-executed, it has to dynamically mix a detailed understanding of the organization's needs with a grasp of the applicant's responses. That plus his/her talents, qualifications, personality, and character, enables the resource personnel make a final decision (Vickers et al., 2014).

\subsubsection{Training and Development}

Training and developing human capital is a crucial necessity which guarantees that staffs are up-to-date with current market trends (Wheelen and Hunger, 2013). This in turn prevents avoidable losses as a result of ignorance (Zhou et al, 2011). Training is done to potentiate the capabilities and abilities of employees. 
Furthermore, it is a means of furthering the knowledge base of employees, while increasing their skills and expertise, which, in the end, improves the organization's overall performance (Bimpitsos and Petridou, 2012).

Training and development demonstrates an organization's formal, ongoing effort to enhance its performance as well as grant employee self-fulfillment via a variety of educational methods and programs. These efforts have taken upon themselves a vast range of applications in the modern workplace, ranging from instruction in highly specific work skills to long term professional development. Recently, training and development is beginning to be recognized as a profession with distinct theories and methodologies, an integral element of strategy, and a formal business function. Many more companies are coming to accept "continual learning" and other aspects of training and development as a way of enhancing growth and obtaining a highly skilled employee base. More to the point, the worth of an organization's staff and their continued skill and productivity development through training is increasingly being recognized as a crucial factor in guaranteeing a long-term success of small business (Salas, et al 2012). Although new techniques are continuously being developed, quite a number of common training procedures have been shown to be highly effective. The traditional learning and development initiatives when mixed with several different methods results in an effective training program (Dirani, 2012).

\subsubsection{Performance Appraisal}

This is simply the appraisal of an employee's performance by a superior. As far as human resource management is involved, there will always be an inclination towards performance assessment (Cystuli and Jacobs, 2012). There are three major reasons for performance assessment. One, it provides a two-way system of feedback, linking the employee and supervisor. Two, it develops the performances of employees. Three, it provides documented evidence of employees' performances for future references and legal reasons (Dirani, 2012). Also, it may be considered when a firm is deciding on promotions and salary increments.

It has been said that assessment of performance is an investment for a company. This argument can be justified by the following advantages: (Dirani, 2012)

- Promotion: Assessment of performance enables supervisors take full advantage of promotional programs for really effective employees.

- Compensation: Assessment of performance enables supervisors take advantage of compensation packages for effective employees.

- Employees' Development: The method of assessment of appraisal enables supervisors properly structure training policies and programs.

- Selection Validation: Assessment of performance enlightens supervisors on the validity and necessity of the selection process.

- Communication: Effective communication within an organization is extremely important, especially the one that exists between an employer and his/her employee.

- Motivation: Performance assessment is motivating. It helps to determine an employee's efficiency, if his/her targets are attained. This will in turn inspire the employee to do a better job next time, which inevitably improves his/her future performances.

\subsubsection{Rewards System}

This is a system in which employees are rewarded to motivate them to greater heights. Organizations have to understand and then reciprocate employees' efforts, contribution, and achievement in the course of his/her duty (Newman and Sheikh, 2012). This serves as an inspiration to the rewarded employee and the whole staff, which, in turn, increases competition and the drive for excellence among the staff. The ultimate beneficiary of this race for excellence is the organization. Previous researches have exposed the link between rewarding hard-work and improvements in employees' performances (Longenecker et al, 2013). Although system of rewards depends on other factors like experience, seniority, and qualification, the dominating factor remains performance. This is why good performances are always equated to better rewards (Alvesson, 2005). Finally, every detail of the rewards program must be properly communicated to employees, for the program to be successful. This is because an individual can only be motivated to work if he/she understands what is required of him/her (Marx et al, 2013). Rewards programs are varied and are aimed at both individual and team performance: variable pay, bonuses, profit sharing, and stock option.

\subsection{Organizational Commitment}

There is an increasing trend whereby organizations are developing an interest in promoting commitment among employees so as to benefit from the resulting boost in employee performance as well as reduction of employee 
turnover. However, several definitions of organizational commitment have surfaced from various quotas. From the varied definitions, organizational commitment can be coined to mean the link between an individual and an organization, as well as the beliefs in the goals of the organization thus making tremendous efforts to reach the goals of the organization by being a part and parcel of it (Amari, 2012; Mahadeen et a., 2016). Allen and Mayor (1990) conducted a study which has dominated the academic field of organizational commitment. In their study, they found that organizational commitment can be subdivided into three major components, namely normative commitment, affective commitment, and continuance commitment. Therefore, the research paper will discuss organizational commitment in accordance with the findings of Allen and Meyer (i.e., the three components of organizational commitment) (Meyer and Allen, 1990).

\subsubsection{Affective Commitment}

Meyer, et al. (2007) defined affective commitment as a positive attachment between employees and an organization. It is the strong commitment of an employee to an organization, which is demonstrated by the employee identifying with the goals of the organization and his/her unwavering desire to remain part and parcel of the organization. It forms the 'desire' component of organizational commitment (Solinger et al., 2008). Affective commitment can be built through open organizational communication, involving employees in decision making, especially on issues directly affecting their areas of expertise and/or welfare, and enabling employees to access organizational information (Dirani \& Kuchinke, 2011). Human resource management practices are instrumental in contributing to the feeling of comfort and competence among employees thus heightening affective commitment among the workers (Dirani \& Kuchinke, 2011). The challenge of this commitment component, however, is that the characteristics of affective commitment components can only be seen but can hardly be defined.

\subsubsection{Continuance Commitment}

Continuance commitment is a feeling of commitment among employees to their organization after considering the possible cost of walking away from the firm (Duffy, et al., 2012). It is the 'need' dimension among employees in an organizational setting. It is brewed when an employee remains loyal and committed to the firm due to the high cost of losing the organizational membership (Ahmad \& Oranye, 2010). The cost of organizational membership in this case may include the loss of such human resource benefits as employee training and development, as well as the rewards systems in the organization (Meyer et al., 2007). The 'side bets' that the employee may suffer by leaving the organization are the forces that develop employee commitment to the organization. However, the 'side bets' do not come all at once, but merge with the age and working period of an employee. Two factors act as the foundation of continuance commitment. The factors are lack of alternative employment for the employee and the amount of investment ploughed into the organization by the employee. However, leaving the organization unaware of the cost of exit does not amount to continuance performance (Dressler, 1999). In this case, it is clearly evident that there is a substantial relationship between human resource practices and the level of commitment exhibited by employees who will feel disadvantaged if they were to leave the organization for any reason (Anton, 2009).

\subsubsection{Normative Commitment}

This form of commitment is formed when the employee feels the urge to work for the organization for ethical reasons. In this case, the idea of leaving the organization is not in the picture (Meyer and Smith, 2000). Previous researches have converged in defining normative commitment among employees as feeling of an ethical obligation to stick with the organization (Mowday et al., 2013). The research points out to a possible link between the process of socialization prior to and after gaining entry into the firm and the treatment during the employee's tenure in the organization. Such human resource practices contribute largely to enhancing normative commitment among the employees (Kanter, 1968). An organization may invest a huge amount on the training of its employees. As a result, the employees will feel morally obliged to return the favor by aiming at achieving the goals of the organization (Imran and Ahmed, 2012). This form of commitment brings forward the 'ought to' component of employees' urge to work tirelessly towards achieving the objectives and standards of the organization.

From the above discussion, there is a substantial argument as to the relationship between the human resource practices mentioned and the three components of commitment as researched by Allen and Meyer (1990).

\subsection{Relationship between HR Practices and Employee Commitment}

It has been revealed time and again by many studies that there exists a connection between employees' commitment in a company and the process of human resource management of that company (Foss et al., 2015). 
These studies consistently and independently point to this connection as well as show its significance. Furthermore, these studies have come to the realization that human resources is the greatest asset of a company, not only because these assets control other company assets, but also they determine the success or failure of a company. More so, these assets make the company to have a competitive advantage over other companies in the same field. Notwithstanding, it is crucial to come to the understanding that it is more expensive and challenging, generally, to manage human resources than any other resources in a company. If the management of human assets is successful, then the organization will be successful, and vice versa.

Researchers have dedicated a lot of time and resources to study organizational commitment, and as a result, many concepts have been introduced and many measures have been tested and proposed (Meyer and Smith, 2000; Shore and Wayne, 1993). Commitment has been broken down into three different themes: affective commitment, continuance commitment, and normative commitment (Meyer and Smith, 2000). Affective commitment was defined by Allen and Meyer (1990) as an affective or emotional attachment to an organization such that the strongly committed individual identifies with, is involved in, and enjoys membership in the organization. This approach was studied extensively by Mowday et al. (2013), and they defined organizational commitment as the relative strength of an individual's identification with and involvement in a particular organization (Mowday et al., 2013). Hence, the following are the characteristics of an employee who is affectively committed or emotionally attached to an organization: (1) he invests in the goals and values of the organization, (2) he works hard to achieve these goals, and (3) he plans on staying with the organization (Mowday et al., 2013). Continuance commitment was defined and Allen and Meyer (1990) as a tendency to engage in consistent lines of activity based on an individual's recognition of the costs associated with discontinuing the activity. Continuance commitment was better defined by Kanter (1968) as follows: "cognitive-commitment is that which occurs when there is a profit associated with continued participation and a cost associated with leaving. Hence, while affective commitment is emotional, continuance commitment emphasizes the calculative side of the relationship between staff and company (Meyer et al., 2007).

Normative commitment is simply the sense of obligation to remain at one's post. This occurs when an employee feels obligated to remain at the job, even though he/she sees better opportunities elsewhere or he/she feel unhappy with the job. He/she feels that he/she must remain with the organization simply because it is right. There are several factors that contribute to developing the sense of obligation. One of these factors is the amount of money and time the organization has invested in the employee's training. Another is the advanced reward the organization provided, such as college tuition. Upbringing might be another factor, where an employee's family pressures the employee to remain loyal to his/her organization.

Perceived economic advantage gained by remaining in one's job, relative to alternative employment opportunities, explained 18 individual's intention to remain at their jobs, showing the calculative aspect of an employment relationship (Meyer and Allen, 1997). They proposed two factors that form the basis of continuance commitment development: (1) number of investments an individual makes in his/her present organization, (2) perceived lack of alternatives. The investment can be anything valuable to the individual, which when he leaves would be lost. Hence, the employee perceives the investments as cost related with leaving the organization, which makes him/her remain in the organization (Meyer and Allen, 1997). Furthermore, the dearth in alternative job opportunities causes the perceived cost associated with leaving to skyrocket, hence strengthening the continuance commitment of the employee (Allen and Meyer, 1990). Meyer et al. (2007) concluded that for affective commitment, employees remain in an organization longer because of what he/she wants, whereas for continuance commitment, employees remain in an organization for economic reasons. It should be noted that all the different conceptualization and measures associated with organizational commitment research, plus the varied definitions, share a central thread, which is the psychological attachment to an organization. This means that the employee forms a psychological link to his/her organization (O'Reilly and Chatman, 1986). Mowday et al. (2013) showed that employees committed to the vision of an organization have a tendency to become invested in the organization's goal, which propels him/her to exert considerable effort into the organization as well as to maintain membership. Therefore, it can be seen that though organizational commitment inspires exerted efforts from employees, it also causes employees to remain in the organization.

The exchange in the relationship between an employer and an employee is the basis of an employee's commitment to an organization (Gouldner, 1960; Shore and Tetrick, 1991). Social exchange theory has been used to investigate this exchange relationship. Gouldner (1960) explained that in social exchanges, obligations are not specified and an individual favors another, expecting something in return-although the time of occurrence and the form is unclear. It may also involve reciprocity, which has become a norm in which the recipient of a benefit is obligated to repay in some form (Gouldner, 1960). Hence, an employee's relationship 
with his/her employer may be viewed as a social exchange. The employer may reward an employee as a way of acknowledging the employee's efforts, and in return the employee decided to become more committed in the organization (Rees \& Smith, 2014). Eisenberger et al. (1990) stated that reciprocity is important in the development of organizational commitment and that employees have a tendency to become more committed in an organization if their efforts are being acknowledged and rewarded. Factors that increase organizational commitment among employees have been identified as human resource management practices and policies (Ogilvie, 1986; Meyer \& Smith, 2000; Arthur, 1994). Oligivie's (1986) proposition, of which social exchange theory formed the basis, was that an employee's perception of human resource management practices determines his/her sense of reciprocity as well as the level of the employee's level of organizational commitment to the organization. The result is that employees believe that the organization will provide symbolic and tangible rewards in exchange for their efforts and commitment. Therefore, it has been proposed that resource management practices are practical ways in fostering employee commitment, and it has been discovered that there is a positive relationship between human resource management practices and organizational commitment. Undeniably, organizational commitment was determined to relate to training, salary levels, performance-reward contingencies, promotion and profit sharing (Coyle-Shapiro et al., 2002).

After exploring the effects of training on organizational commitment, Barrett and O'Connell (2001) discovered that perceived access to training produced the highest organizational commitment. From the results, it was seen that employees perceived training as support from their employers, which made them more committed to their organization. Also, it was reported that a significant positive relationship existed between organizational commitment and perceived support for training from colleagues and management. From the results, it was seen that the employee's perception of the managements support for the training programs influenced his/her attitude and perception in the training. Nevertheless, most prior research have centered on individual human resource management practices. Wilkinson et al. (1996) pointed out that specific human resource management styles are suitable for specific circumstances. Ogilvie (1986) argued that human resource management practice cannot significantly influence commitment levels. Therefore, when human resource management practices are part of a systematic program, which is when they can best affect commitment levels. Some researchers have centered on specific configurations of this practice (Arthur, 1994; Becker \& Gerhart, 1996). Thus, human resource management practices influence organizational commitment when they are implemented at the same time (Pathak et al., 2005). According to Chang (2005), diverse practices such as training, sharing information, employment security, performance based compensation, employee participation, and ensuring employees' well-being are all included in a commitment human resource management bundle. It was reported by Arthur (1994), when he collected data from 30 steel mills, that organizations that emphasized the development of employee commitment (organizations with "commitment" human resource systems) experienced greater productivity as measured by lower scrap rates and lower employee turnover than organizations that emphasized efficiency and reduction of costs ("control" systems). Therefore, there are many studies reporting the effect of human resource management on company's performance and few on employee attitude (Arthur, 1994). Chang (2005) suggested the constant messaging of employees by employers about their commitment to the employees as a reason for increased organizational commitment; the messages caused employees to be more committed. Very few researchers study the relationship between organizational commitment and human resource management practices in spite of the huge impact one has on the other (Arthur, 1994; Chang, 2005; Meyer and Smith, 2000; Ogilvie, 1986). Rather, they have centered on the relationship between human resource management practices and organizational performance. On the basis of the exchange theory approach to commitment, Ogilvie (1986) accorded importance to employees' perception of human resource management practices. Among the few studies on this matter, Chang's (2005) holistically analyzed human resource management practices at the organizational level and discovered a significant positive relationship with employees' overall perception of the human resources management practices of the organization at the individual level. An employee's perception of an organization's human resource management practices was considered an important factor in gaining an understanding of the employee's changing behaviors as he/she is exposed to different human resource management practices (Chang, 2005). Chang (2005) went ahead to determine how overall perception affects organizational commitment.

Previous research have studied how organizational commitment is influenced by human resource management practices such as: training and organizational commitment (Barrett and O'Connell, 2001), salary levels and organizational commitment (Foss et al., 2015), performance reward contingencies and organizational commitment (Rhodes and Steers, 1981), promotion and organizational commitment (Kanter, 1968; Niki, 2012), and profit sharing and organization commitment (Coyle-Shapiro et al., 2002). Arthur's (1994) proposition was that certain combinations of policies and practices can be used to predict differences in turnover and performance. 
This suggests that it is more important to study the effect of a combination of specific human resource management practices (rather than one) on organizational commitment, because organizations make use of more than one practice. As a result, this study uses a combination of eight human resource management practices. Furthermore, in this study, instead of questioning employees on their overall perception of the organizations' human resource management practices effectiveness, employees' perceptions about training, performance appraisal, rewards, benefits, working conditions, equal employment opportunity, and information sharing were assessed. Therefore, in this study, eight human resource management practices' influence on organizational commitment will be examined. Note that these eight human resource management practices were obtained from other studies that showed that these practices had significant effects on organizational commitment. From Edgar and Geare's (2005) study of the influence of human resource management practices on organizational commitment, recruitment and selection, training and development, equal employment opportunities, and good and safe working conditions were included. These practices were found to be positively and significantly related to organizational commitment. From Chang's (2005) study of the influence of employees' overall perception of the organization's human resource management practices on organizational commitment, performance appraisal was included. It was demonstrated that higher organizational commitment resulted from employees' beliefs that human resource management practices of the organization were effective. Another factor included in the study is performance appraisal, along with training effectiveness, staffing, grievance system, and suggestion system effectiveness. In this study, grievance system and suggestion system were included as information sharing.

The study by Kinicki et al. (1992) gave more support to information sharing as an influencing factor. From the results, it was seen that employee work habits are influenced by real human resource programs. The authors have built on these results by proposing that in addition to using other human resource management practices (training, staffing, etc.), when an organization shares information with its employees and requests employees' suggestions, employees begin to believe that the organization supports and are committed to them. This positive impression spurs positive employee attitude. As a result, information sharing was included in this study because past literature provided ample support for its significant effect on organizational commitment. The study by Lucero and Allen (1994) informed the inclusion of benefits. Over the years, there has been an increase in the number of employee benefits provided by employers and an equal increase in the costs associated with these benefits. To cut down on labor expenses, organizations are now decreasing benefit packages. Notwithstanding, many employees have come to depend on employer-provided benefits to help satisfy basic security needs. This has created a conflict between employers' practices and workers' expectations, resulting in a violation of employees' psychological contract. The study proposes several ways of resolving this conflict, which would result in a fulfillment of the psychological contract. In the same vein, Coyle-Shapiro et al. (2002) study showed 25 advantages of profit sharing to organizational commitment. Arthur (1994), on the other hand, showed the advantages of wages and bonuses to organizational performance.

\section{Theoretical Framework}

The model illustrated in Figure 1 was constructed according to the objectives of the present study. The hypothesized linkage indicates that human recourse management practices are linked to organizational commitment. As discussed earlier, human recourse management practices is assumed to influence the organizational commitment and improve the levels of loyalty of employees in organizations. Human resources management practices were measured using recruitment methods, training and development, performance appraisals, and reward systems (Lim \& Ling, 2012). Organizational commitment was measured using three dimensions of affective commitment, continuance commitment, and normative commitment (Allen \& Meyer, 1990). The research model is displayed in Figure 1 where Human resource practices represent the independent variables, while organizational commitment represents the dependent variable.

\begin{tabular}{|c|c|}
\hline Independent Variable & Dependent Variable \\
\hline $\begin{array}{l}\text { HRM Practices } \\
\text { - Performance } \\
\text { Appraisal } \\
\text { - Recruitment and } \\
\text { Selection } \\
\text { - Reward System } \\
\text { - } \\
\text { Training and } \\
\text { Development }\end{array}$ & $\begin{array}{l}\text { Organizational } \\
\text { Commitment } \\
\text { - Affective } \\
\text { Commitment } \\
\text { - Normative } \\
\text { Commitment } \\
\text { - Continuance } \\
\text { Commitment }\end{array}$ \\
\hline
\end{tabular}

Figure 1. The research model and the hypothesized relationships based on the human resource management practices and the organizational commitment 


\subsection{Operational Definitions}

\subsubsection{Human Resource Management Practices (Independent Variable)}

Human resource practices can be defined as efforts marshaled by organizations in ensuring proper management of its pool as a way targeting the achievement of organizational goals (Armstrong, 2013). In the present study, the practices have been grouped in four major categories such as the methods of recruiting, training and development, the reward systems, and appraisals of employee performance. Recruitment Methods refers tothe success of organization solely leans on the employees; hence, there is need for the organization to scout for the best staff during its process of recruiting employees (Foss et al., 2015). Training and development refers tothe training and development of human capital which is of pivotal role in ensuring that the employees are abreast with the market trends thus avoiding any incidents of losses resulting from ignorance of the staff (Zhou et al., 2011). Performance appraisal is a systematic way assessing performance of the employee by a supervisor. Performance appraisal is a trend far as human resource management practice is concerned (Cystuli and Jacobs, 2012). Reward Systems is a structured system in which employees are rewarded as a way of motivating. There is a need for companies to recognize, appreciate, as well as reciprocate the efforts, contribution and achievements of an employee in the course of his or her duty (Newman and Sheikh, 2012).

\subsubsection{Organizational Commitment (Dependent Variable)}

Organizational commitment has been defined in various ways (Mowday et al., 2013). According to Greenberg and Baron (2003), Organizational commitment was proposed as the extent to which an individual identifies, and involves with his or her organization and/or the willing to leave it. Furthermore, Myer and Herscovitch (2001, p. 301) defined commitment as: "a force that binds an individual to a course of action of relevance to one or more targets". In the present study, organizational commitment was defined depending on the three component model of commitment developed by Meyer and Allen (1997) who proposed that organizational commitment was experienced by the employees as affective commitment, continuance commitment, and normative commitment. Affective commitment reflects commitment based on emotional ties the employee develops with the organization primarily via positive work experiences, whereas normative commitment reflects commitment based on perceived obligation towards the organization, for example: routed in the norms of reciprocity. Furthermore, continuance commitment reflects commitment based on the perceived cost both economic and social of leaving the organization.

The tool used in the present study ((the organizational commitment questionnaire (OCQ)) developed by Porter et al. (1974) is one of the most common methods of assessing the type of organizational commitment utilized in many studies. The constructs with their measures are shown in Appendix 1.

\subsection{Hypotheses}

Based on the theoretical framework displayed in Figure 1, the hypotheses standing behind the present study were as follows:

H1: There is an effect of human recourse practices on organizational commitment in chain pharmacies in Jordan.

H1.1: There is an effect of recruitment and selection on affective commitment in chain pharmacies in Jordan.

H1.2: There is an effect of training and development on affective commitment in chain pharmacies in Jordan.

H1.3: There is an effect of performance appraisal on affective commitment in chain pharmacies in Jordan.

H1.4: There is an effect of reward system on affective commitment in chain pharmacies in Jordan.

H2.1: There is an effect of recruitment and selection on continuance commitment in chain pharmacies in Jordan.

H2.2: There is an effect of training and development on continuance commitment in chain pharmacies in Jordan.

H2.3: There is an effect of performance appraisal on continuance commitment in chain pharmacies in Jordan.

H2.4: There is an effect of reward system on continuance commitment in chain pharmacies in Jordan.

H3.1: There is an effect of recruitment and selection on normative commitment in chain pharmacies in Jordan.

H3.2: There is an effect of training and development on normative commitment in chain pharmacies in Jordan.

H3.3: There is an effect of performance appraisal on normative commitment in chain pharmacies in Jordan.

H3.4: There is an effect of reward system on normative commitment in chain pharmacies in Jordan.

\section{Methodology}

Because this study is conducted to examine the relationship between human resource management practice and 
organizational commitment at chain pharmacies in Jordan, the population consists of all levels of pharmacists working in chain pharmacies in Jordan. Pharmacists are active healthcare professionals working in a semi-commercial health organization and chain pharmacies are firms that have a clear organizational structure with active HR department when compared to single pharmacies. Accordingly, the population of this study is composed of pharmacists working in different chain pharmacies in Jordan. At the time of the study 200 pharmacists were working in both of the organizations (chain pharmacies) taking part in the study, questionnaires were sent to the whole population.

In order to ensure a high response rate, a cover letter accompanied each questionnaire to respondents explaining the research objectives with the assurance of the confidentiality of the information they provided. Each cover letter was sent directly to the pharmacists in the branches where they were working, and they were asked to fill in the survey. To enhance the response rate, questionnaires were delivered and collected in person. The letter offered a brief introduction to the research and its objectives, and requested written consent from those pharmacists who were willing to take part in the study. Pharmacists were given one week to fill the questionnaires before the first round of collection. Those who failed to complete the questionnaire were given another week notice before the second round of collection.

A total of 200 questionnaires were distributed to pharmacists working in chain pharmacies in Jordan and 125 completed the questionnaire indicating a $62.5 \%$ response rate. It is recommended in previous research that a feasible sample size should be between 100 and 200, in order to be adequate for the data analysis (Obeidat et al. 2013). Hence, our sample size is considered adequate for the data analysis. This questionnaire is composed of 40 questions that represent all the variables of this research. The respondents answered all items on five point Likert-scales ranging from " 1 " of "strongly disagree" to "5" of "strongly agree". Further, elements used to consider each of the constructs were primarily obtained from prior research. These elements provided a valued source for data gathering and measurement as their reliability and validity have been verified through previous research and peer review.

\section{Data Analysis}

\subsection{Instrument Validity and Reliability}

The first step was to ensure face and content validity. To do this, the researcher adopted scales and items that were previously developed and used by other researchers with similar interest. Also a draft of the questionnaire was formulated, and then it was reviewed by six academic lecturers -who have sufficient knowledge and experience in this scope- to insure that each item is measuring what is intended to be measured, and to avoid the ambiguity and complexity in the phrasing of questions.

In order to test the internal consistency of the constructs being measure, this study used Cronbach's alpha coefficient. According to Hair et al. (2010), Cronbach's alpha coefficient should be above 0.7 to consider reliable. The Cronbach's alpha for the independent variables is as follow: recruitment and selection has a Cronbach's alpha coefficient of 0.821 . compensation and reward has a Cronbach's alpha coefficient of 0.854 . performance appraisal practices has a Cronbach's alpha coefficient of 0.801. training and development has a Cronbach's alpha coefficient of 0.821 . The Cronbach's alpha for the dependent variables is as follows: affective commitment has a Cronbach's alpha coefficient of 0.621 , continuance commitment has a Cronbach's alpha coefficient of 0.722 , and normative commitment has a Cronbach's alpha coefficient of 0.792. The Cronbach's alpha coefficients of all variables are listed in Appendix 1.

\subsection{Respondents Demographics}

This study aimed to finding a relationship between human resource management practices and organizational commitment among pharmacists working in chain pharmacies in Jordan. Of the 125 completed questionnaires. More than two thirds of respondents were female $(n=86,68.8 \%)$ and the majority of respondents $(n=73,58.4 \%)$ were of ages between 20 to 30 years old. All respondents were pharmacists holding a BSc $(n=94,74.2 \%)$ or a PharmD $(n=31,24.8 \%)$ degree. A minority of respondents had a postgraduate degree (MSc; $n=17,13.6 \%)$ and most of them has experience less than 10 years $(n=78,62.4 \%)$. Table 1 illustrates demographic characteristics of respondents. 
Table 1. Demographic characteristics of respondents

\begin{tabular}{lll}
\hline Respondent's characteristics & Frequency & Percentages \\
\hline Gender & 86 & 68.8 \\
Male & 39 & 31.2 \\
Female & & 58.4 \\
Age & 73 & 32.8 \\
$20-30$ & 41 & 8.8 \\
$31-40$ & 11 & 0 \\
$41-50$ & 0 & \\
Above 50 & & 32.8 \\
Experience & 41 & 29.6 \\
$0-5$ years & 37 & 20.8 \\
6-10 years & 26 & 10.4 \\
$11-15$ years & 13 & 6.4 \\
$16-20$ years & 8 & \\
More than 20 years & & 74.2 \\
Education & 94 & 24.8 \\
BSc Pharmacy & 31 & 64.0 \\
PharmD (Doctor of Pharmacy) & & 28.0 \\
Level of appointment & 80 & 8.0 \\
Staff Pharmacist & 35 & \\
Chief Pharmacist & 10 & \\
Branch Manager & & \\
\hline
\end{tabular}

\subsection{Descriptive Analysis for the Independent and Dependent Variables}

The descriptive statistics of the constructs used in the proposed research model can be shown Appendix 1. All means were above the mid-point of 2.5 and most of the variables were classified "high". The results show that the majority of respondents express generally positive answers to the variables used in the research model. The results in Appendix 1 also show that the standard deviations ranged from 1.10 to 1.37 which indicate a narrow spread around the mean.

\subsection{Hypothesis Testing}

The first set of multiple regression analyses was conducted with affective commitment as the dependent variable. As expected training and development and reward system were positively and significantly related to affective commitment $(\mathrm{P}<.0 .05)$. The relationship between performance appraisal and affective commitment and recruitment and selection and affective commitment was found to be positive but did not exhibit a statistical significance. The results of these analyses are presented in Table 2.

The overall model was significant when continuance commitment was entered as the dependent variable. The relationships between continuance commitment and both reward system and recruitment and selection was significant $(\mathrm{P}<0.05)$. No significant relationships were found between continuance commitment and both performance appraisal and training and development $(\mathrm{P}>0.05)$. The results of these analyses are presented in Table 2. No significant relationships were found between normative commitment and any of the suggested human recourse management practices. 
Table 2. Results of the analyses for human resource practices on affective, continuance, normative commitment

\begin{tabular}{|c|c|c|c|c|c|c|}
\hline Independent variables & $\begin{array}{l}\text { Unstandardized } \\
\text { B }\end{array}$ & $\begin{array}{l}\text { Standard } \\
\text { error }\end{array}$ & $\begin{array}{l}\text { Standardized } \\
\beta\end{array}$ & R Square & $\begin{array}{l}\text { Adjusted } \\
\text { R Square }\end{array}$ & Significance \\
\hline Affective commitment & & & & 0.087 & 0.069 & 0.000 \\
\hline Recruitment and selection & 0.039 & 0.048 & 0.055 & & & \\
\hline Training and development & 0.091 & 0.041 & $0.124 *$ & & & \\
\hline Performance appraisal & 0.109 & 0.040 & 0.277 & & & \\
\hline Reward system & 0.111 & 0.047 & $0.137 *$ & & & \\
\hline Continuance commitment & & & & 0.029 & 0.021 & 0.071 \\
\hline Recruitment and selection & 0.042 & 0.061 & $0.051^{*}$ & & & \\
\hline Training and development & 0.017 & 0.059 & 0.018 & & & \\
\hline Performance appraisal & 0.099 & 0.059 & 0.131 & & & \\
\hline Reward system & 0.160 & 0.071 & $0.009^{*}$ & & & \\
\hline Normative commitment & & & & 0.011 & -0.008 & 0.611 \\
\hline Recruitment and selection & 0.009 & 0.057 & 0.019 & & & \\
\hline Training and development & 0.009 & 0.057 & 0.013 & & & \\
\hline Performance appraisal & 0.049 & 0.045 & 0.090 & & & \\
\hline Reward system & 0.199 & 0.059 & 0.299 & & & \\
\hline
\end{tabular}

\section{Discussion, Recommendations, Limitations and Future Research}

The primary purpose of this study was to evaluate the impact of several human resource management practices on organizational commitment among pharmacists working in chain pharmacies in Jordan. In contrast to single pharmacy shops, chain pharmacies demonstrate a complete organizational model and are worth studying. So far there has not been any study published in the literature that surveys such a topic.

It has been hypothesized that the following practices were related to organizational commitment: (1) recruitment and selection; (2) training and development; and (3) reward system.

For the affective commitment hypotheses H1.2 and H1.4 were confirmed. For the continuance commitment hypotheses H2.1 and H2.4 were confirmed. None of the hypothesis related to normative commitment were confirmed.

As can be noticed from the results section, the affective component of organizational commitment of respondents depends on training and development and reward system. Training and development is an important factor in increasing employees' commitment. Decreasing rates of affective commitment have been found among employees working in work places that do not offer robust training programs (Chaudhuri, 2010). Employees' affective commitment to the organization is a valuable and intangible asset, which can generate tangible long-term benefits. Organizations should focus on developing initiatives that matter most to the affective form of the commitment as it is seen to be a crucial driver in predicting employee turnover (Meyer \& Herscovitch, 2001). Results supported the hypothesis that fair rewards are positively related to affective commitment. The Mercer report (2003) demonstrated that employees who are rewarded fairly will be more committed and stay. Companies that use the reward budget effectively to distribute the rewards adequately among top performers receive an increased consideration than other companies.

Furthermore, human resource management practices are positively associated with continuance commitment by making it costly for employees to leave (e.g., chances for promotion and efforts recognition would be lost). The results show that only fair rewards and recruitment and selection were significantly associated with continuance commitment. This could be due to the fact that the majority of pharmacists in Jordan have very little options in the pharmaceutical marketplace, and are likely to be committed to their organization not only emotionally but also because of the lack of other or better job opportunities. Our findings are consistent with the human capital theory (Becker \& Gerhart, 1996), which indicates that employees stay because of the fewer opportunities they have elsewhere due to the difficulties in exporting the acquired knowledge outside the company. The human resource management practices did not contribute significantly to the prediction of the normative commitment. The obligation to remain in the organization (normative commitment) is developed independently. Again, due to the fact that the pharmacy workplace has little diversity and pharmacists do not have many opportunities, the ethical contract between employers and employees are violated; there is then no obligation on the part of employees to respect their contract. 
Based on the results of this study we recommend the following: further research could clarify the causal relationship between human recourse management practices and organizational commitment. Much of the research on human recourse management practices has been conducted in western societies; thus, the findings of this study can be useful in future comparative studies. Further studies should take into consideration more human resource management practices, other factors than those studied in this study. It is hoped that the results of the present study serve as a benchmark for future studies and research in this area. Training and development should be studies as a single factor in affecting organizational commitment among employees in healthcare system as it was shown to be positively related to all types of organizational commitment.

Any with any other research, this study has some limitations. First of all, the sample of respondents is mainly based on a specific country, Jordan, which explains why some hypotheses have been rejected, maybe due to cultural autonomy of Middle Eastern countries. Secondly, this study has investigated only one industry, community pharmacy, which may have limitations for generalization to other sectors especially that pharmacy, represents a mix between healthcare and business. Thirdly, only four human recourse management practices were investigated in this study. There are probably other human recourse management practices that have a significant impact on the level of employee commitment and which are not taken into consideration in this research.

\section{References}

Ahmad, N., \& Oranye, N. O. (2010). Empowerment, job satisfaction and organizational commitment: A comparative analysis of nurses working in Malaysia and England. Journal of Nursing Management, 18(5), 582-591. https://doi.org/10.1111/j.1365-2834.2010.01093.x

Al-Azmi, N., Al-Lozi, M., Zu'bi, Z., \& Dahiyat, S. (2012). patients attitudes toward service quality and its impact on their satisfaction in physical therapy in KSA hospitals. European Journal of Social Sciences, 34(2), 300-314.

Alkalha, Z., Al-Zu'bi, Z., Al-Dmour, H., \& Alshurideh, M., (2012). Investigating the effects of human resource policies on organizational performance: An empirical study on commercial banks operating in Jordan. European Journal of Economics, Finance and Administrative Sciences, 51(1), 44-64.

Allen, N. J., \& Meyer, J. P. (1990). The measurement and antecedents of affective, continuance and normative commitment to the organization. Journal of occupational psychology, 63(1), 1-18. https://doi.org/10.1111/j.2044-8325.1990.tb00506.x

Almajali, D. A., Masa'deh, R., \& Tarhini, A. (2016). Antecedents of ERP systems implementation success: A study on Jordanian healthcare sector. Journal of Enterprise Information Management, 29(4), 549-565. https://doi.org/10.1108/JEIM-03-2015-0024

Alrowwad, A., Almoharami, S., Obeidat, B.Y., Tarhini, A., \& Aqqad, N. (2017). The impact of transformational leadership on organizational performance via the mediating role of corporate social responsibility: A structural equation modeling approach. International Business Research, 10(1), 11-25.

Alshurideh, M., \& Alkurdi, B. (2012). The effect of customer satisfaction upon customer retention in the Jordanian mobile market: An empirical investigation. European Journal of Economics, Finance and Administrative Sciences, 47, 69-78.

Al-Sarayrah, S., Obeidat, B.Y., Al-Salti, Z., \& Kattoua, T. (2016). The effect of culture on strategic human resource management practices: A theoretical perspective. International Journal of Business Management and Economic Research, 7(4), 704-716.

Altamony, H., \& Alshurideh, M. (2012). Information systems for competitive advantage: Implementation of an organisational strategic management process. Proceedings of the 18th IBIMA Conference on Innovation and Sustainable Economic Competitive Advantage: From Regional Development to World Economic. Istanbul, Turkey, 9th-10th May.

Altamony, H., Tarhini, A., Al-Salti, Z., Gharaibeh, A. \& Elyas, T. (2016). The relationship between change management strategy and successful enterprise resource planning (ERP) implementations: A theoretical perspective. International Journal of Business Management and Economic Research, 7(4), 690-703.

Alvesson, M. (2005). Knowledge work: Ambiguity, image and identity. Human relations, 54(7), 863-886. https://doi.org/10.1177/0018726701547004

Armstrong, M. (2013). A handbook of personnel management practice. Kogan Page, London:UK. 
Anton, C. (2009). The Impact of role Stress behavior on workers' behavior through job satisfaction and organizational commitment. International Journal of Psychology, 44(1), 32-61.

Arthur, J. (1994). Effects of human resource systems on manufacturing performance and turnover. Academy of Management Journal, 37(3), 670-687. https://doi.org/10.2307/256705

Barrett, A., \& O'Connell, P. J. (2001). Does training generally work? The returns to in-company training. Industrial and Labor Relations Review, 54, 647-662. https://doi.org/10.1177/001979390105400307

Becker, B., \& Gerhart, B. (1996). The impact of human resource management on organizational performance: Progress and prospects. Academy of Management Journal, 39, 779-801. https://doi.org/10.2307/256712

Bimpitsos, C., \& Petridou, E. (2012). A transdisciplinary approach to training: preliminary research findings based on a case analysis. European Journal of Training and Development, 36(9), 911-929. https://doi.org/10.1108/03090591211280964

Blumberg, B., Cooper, D., \& Schindler, P. (2005). Business Research Mehods. London: UK, McGraw Hill.

Chang, E. (2005). Employee's overall perception of HRM effectiveness. Human Relations, 58(4), 523-544. https://doi.org/10.1177/0018726705055037

Chaudhuri, K., (2010). Exploring employee consciousness of HPWS and commitment in Japanese organizations: An empirical approach. Journal of International Business Disciplines, 5(1), 5-24.

Council, N.C., (2013). Recruitment and selection. Managing human resources: personnel management in transition, 5, 115-147.

Coyle-Shapiro, J. A. M., Morrow, P. C., Richardson, R., \& Dunn, S. R. (2002). Using profit sharing to enhance employee attitudes: A longitudinal examination of the effects on trust and commitment. Human resource management, 41(4), 423-439. https://doi.org/10.1002/hrm.10052

Cystuli, M. D., \& Jacobs, L. (2012). Affective organizational commitments as a predictor of military enlistment discussion. International Journal of Business, Humanities and Technology, 2(3), 15-27.

Dirani, K. M., \& Kuchinke, K. P. (2011). Job satisfaction and organizational commitment: validating the Arabic satisfaction and commitment questionnaire (ASCQ), testing the correlations, and investigating the effects of demographic variables in the Lebanese banking sector. The International Journal of Human Resource Management, 22(05), 1180-1202. https://doi.org/10.1080/09585192.2011.556801

Dirani, K. M. (2012). Professional training as a strategy for staff development: A study in training transfer in the Lebanese context. European Journal of Training and Development, 36(2/3), 158-178. https://doi.org/10.1108/03090591211204698

Dressler, G. (1999). How to earn your Employees Commitment. Academy of Management Executives, 13(2).

Duffy, R. D., Bott, E. M., Allan, B. A., Torrey, C. L., \& Dik, B. J. (2012). Perceiving a calling, living a calling, and job satisfaction: testing a moderated, multiple mediator model. Journal of Counseling Psychology, 59(1), 50-59. https://doi.org/10.1037/a0026129

Edgar, F., \& Geare, A. (2005). HRM practice and employee attitudes: Different measures-different results. Personnel review, 34(5), 534-549. https://doi.org/10.1108/00483480510612503

Eisenberger, R., Fasolo, P., \& Davis-LaMastro, V. (1990). Perceived organizational support and employee diligence, commitment, and innovation. Journal of Applied Psychology, 75(1), 51. https://doi.org/10.1037/0021-9010.75.1.51

El-Masri, M., Orozco, J., Tarhini, A., \& Tarhini, T. (2015). The impact of IS-Business alignment practices on organizational choice of IS-Business alignment strategies. The 19th Pacific Asia Conference on Information Systems (PACIS 2015), Paper 215, Singapore, 6-9 July 2015.

Foss, N. J., Pedersen, T., ReinholtFosgaard, M., \& Stea, D. (2015). Why complementary HRM Practices Impact Performance: The Case of Rewards, Job Design, and Work Climate in a Knowledge-Sharing Context. Human Resource Management, 54(6), 955-976. https://doi.org/10.1002/hrm.21649

Gouldner, H. P. (1960). Dimensions of organizational commitment. Administrative Science Quarterly, 4(4), 468-490. https://doi.org/10.2307/2390769

Greenberg, J., \& Baron, R. A. (2003). Behavior in organizations: Understanding and managing the human side of work. Pearson College Division. Canada, Ont.: Prentice-Hall. 
Hair, J. F., Anderson, R. E., Tatham, R. L., \& Black, W. C. (2010). Multivariate Data Analysis (7th ed.). Upper Saddle River, NJ: Prentice Hall.

Hajir, J. A., Obeidat, B. Y., \& Al-dalahmeh, M. A. (2015). The role of knowledge management infrastructure in enhancing innovation at mobile telecommunication companies in Jordan. European Journal of Social Sciences, 50(3), 313-330.

Hamoud, M., Tarhini, A., Akour, M. A. \& Al-Salti, Z. (2016). Developing the main knowledge management process via social media in the IT organisations: A conceptual perspective. International Journal of Business Administration, 7(5), 49-64.

Hassouna, M., Elyas, T. \& Abou Trab, M. S. (2015). Customer churn in mobile markets: A comparison of techniques. International Business Research, 8(6), 224-237. https://doi.org/10.5539/ibr.v8n6p224

Imran, A., \& Ahmed, M. (2012). Impact of human resource practices on organizational commitment: A study among service sector employees in Pakistan. Interdisciplinary Journal of Contemporary Research in Business, 4(2), 81-94.

Kanaan, R., \& Gharaibeh, A. (2013). The impact of knowledge sharing enablers on knowledge sharing capability: An empirical study on Jordanian telecommunication firms. European Scientific Journal, 9(22), 237-258.

Kanter, R. M. (1968). Commitment and social organization: A study of commitment mechanisms in utopian communities. American sociological review, 33(4), 499-517. https://doi.org/10.2307/2092438

Kinicki, A. J., Carson, K. P., \& Bohlander, G. W. (1992). Relationship between an organization's actual human resource efforts and employee attitudes. Group \& Organization Management, 17(2), 135-152. https://doi.org/10.1177/1059601192172003

Lim, L. J., \& Ling, F. Y. (2012). Human resource practices of contractors that lead to job satisfaction of professional staff. Engineering, Construction and Architectural Management, 19(1), 101-118. https://doi.org/10.1108/09699981211192599

Longenecker, J., Petty, J., Palich, L. \& Hoy, F., (2013). Small business management. Cengage Learning.

Lucero, M. A., \& Allen, R. E. (1994). Employee benefits: A growing source of psychological contract violations. Human Resource Management, 33(3), 425-446. https://doi.org/10.1002/hrm.3930330310

Mahadeen, B., Al-Dmour, R., Obeidat, B. Y., \& Tarhini, A., (2016). Examining the effect of the organization's internal control system on organizational effectiveness: A Jordanian empirical study. International Journal of Business Administration, 7(6), 22-41. https://doi.org/10.5430/ijba.v7n6p22

Masa'deh, R., Shannak, R. Maqableh, M. \& Tarhini, A. (2017). The Impact of knowledge management on job performance in higher education: The case of the University of Jordan. Journal of Enterprise Information Management, 30 (3).

Masa'deh, R., Obeidat, B., \& Tarhini, A. (2016). A Jordanian empirical study of the associations among transformational leadership, transactional leadership, knowledge sharing, job performance, and firm performance: A structural equation modelling approach. Journal of Management Development, 35(5), 681-705. https://doi.org/10.1108/JMD-09-2015-0134

Masa'deh, R., Al-Dmour, R., \& Tarhini, A. (2015). Knowledge management strategies as intermediary variables between IT-Business strategic alignment and firm performance. European Scientific Journal, 11(7), 344-368.

Masa'deh, R., Tarhini, A., Al-Dmour, R. H., \& Obeidat, B. Y. (2015). Strategic IT-Business alignment as managers' explorative and exploitative strategies. European Scientific Journal, 11(7), 437-457.

Masa'deh, R., Gharaibeh, A., Tarhini, A., \& Obeidat, B. (2015). Knowledge sharing capability: A literature review. Fourth Scientific \& Research Conference on New Trends in Business, Management and Social Sciences, Istanbul, Turkey, 19-20 September 2015 (pp. 1-16). https://doi.org/10.2139/ssrn.2696924

Masa'deh, R., \& Shannak, R. (2012). Intermediary effects of knowledge management strategy and learning orientation on strategic alignment and firm performance. Research Journal of International Studies, 24, $112-128$.

Masa'deh, R. (2012). The impact of management information systems (MIS) on quality assurance (QA): A Case study in Jordan. International Journal of Information, Business and Management, 4(2), 93-110.

Masa'deh, R. (2013). The impact of information technology infrastructure flexibility on firm performance: An 
empirical study of Jordanian public shareholding firms. Jordan Journal of Business Administration, 9(1), 204-224. https://doi.org/10.12816/0002054

Marx, A. E., Du Plessis, A., \& Botha, C. (2013). Suggestion system as an HRM tool to be successful in organisations: some empirical evidence in New Zealand. SSAIMS 2013 Conference Proceedings, 15-17 September, 2013.

Mercer Report. (2003). Mercer study raises red flags for employer pay and benefit plans (findings of the 2002 People at work survey). Human Resource Department Management Report, May, pp. 8-15.

Meyer, J. P., \& Herscovitch, L. (2001). Commitment in the workplace: Toward a general model. Human resource management review, 11(3), 299-326. https://doi.org/10.1016/S1053-4822(00)00053-X

Meyer, J. P., Srinivas, E. S., Lal, J. B., \& Topolnytsky, L. (2007). Employee commitment and support for an organizational change: Test of the three-component model in two cultures. Journal of Occupational and Organizational Psychology, 80(2), 185-211. https://doi.org/10.1348/096317906X118685

Meyer, J. P., \& Allen, N. J. (1991). A conceptualization of organizational commitment. Human Resource Management Review, 1(3), 61-89. https://doi.org/10.1016/1053-4822(91)90011-Z

Meyer, J. P., \& Smith, C. A. (2000). HRM practices and organizational commitment: Test of a mediation model. Canadian Journal of Administrative $\quad$ Sciences, $17(4), \quad 319-331$. https://doi.org/10.1111/j.1936-4490.2000.tb00231.x

Mowday, R. T., Porter, L. W., \& Steers, R. M. (2013). Employee-organization linkages: The psychology of commitment, absenteeism, and turnover. Academic press.

Newman, A., \& Sheikh, A. Z. (2012). Organizational rewards and employee commitment: A Chinese study. Journal of Managerial Psychology, 27(1), 71-89. https://doi.org/10.1108/02683941211193866

Niki, N. (2012). Designing Distribution system of rewards and influence on employees satisfaction case study: Hamgamkhodro Asia factory. International Journal of Business and Social Science, 3(12), 305-312.

O'Reilly, C. A., \& Chatman, J. (1986). Organizational commitment and psychological attachment: The effects of compliance, identification, and internalization on prosocial behavior. Journal of applied psychology, 71(3), 492-503. https://doi.org/10.1037/0021-9010.71.3.492

Obeidat, B. Y., Al-Suradi, M., \& Tarhini, A. (2016). the impact of knowledge management on innovation: An empirical study on Jordanian consultancy firms. Management Research Review, 39(10), 1214-1238. https://doi.org/10.1108/MRR-09-2015-0214

Obeidat, B. Y., Al-Sarayrah, S., Tarhini, A., Al-Dmour, R. H., Al-Salti, Z., \& Sweis, R. (2016). Cultural influence on strategic human resource management practices: A Jordanian case study. International Business Research, 9(10), 94-114. https://doi.org/10.5539/ibr.v9n10p94

Obeidat, B. Y., Hashem, L., Alansari, I, Tarhini, A., \& Al-Salti, Z. (2016). The effect of knowledge management uses on total quality management practices: A theoretical perspective. Journal of Management and Strategy, 7(4), 18-29. https://doi.org/10.5430/jms.v7n4p18

Obeidat, B. Y., El-Rimawi, S. Y., Maqableh, M. M., \& Al-Jarrah, I. M. (2013). Evaluating the profitability of the islamic banks in Jordan. European Journal of Economics, Finance and Administrative Sciences, 56, 27-37.

Obeidat, B., Sweis, R., \& Zyod, D., (2012). The effect of perceived service quality on customer loyalty in internet service providers in Jordan. Journal of Management Research, 4(4), $224-242$. https://doi.org/10.5296/jmr.v4i4.2130

Ogilvie, J. R. (1986). The role of human resource management practices in predicting organizational commitment. Group \& Organization $\quad$ Management, $11(4), \quad 335-359$. https://doi.org/10.1177/0364108286114003

Orozco, J., Tarhini, A., Masa'deh, R., \& Tarhini, T. (2015). A framework of IS/business alignment management practices to improve the design of IT governance architectures. International Journal of Business and Management, 10(4), 1-12. https://doi.org/10.5539/ijbm.v10n4p1

Othman, A. (2009). Strategic integration of human resource management practices: Perspectives of two major Japanese electrical and electronics companies in Malaysia. Cross Cultural Management: An International Journal, 16(2), 197-214. https://doi.org/10.1108/13527600910953937

Pathak, R. D., Budhwar, P. S., Singh, V., \& Hannas, P. (2005). Best HRM practices and employees' 
psychological outcomes: a study of shipping companies in Cyprus. South Asian Journal of Management, $12(4), 7-24$.

Porter, L. W., Steers, R. M., Mowday, R. T., \& Boulian, P. V. (1974). Organizational commitment, job satisfaction, and turnover among psychiatric technicians. Journal of applied psychology, 59(5), 603. https://doi.org/10.1037/h0037335

Rees, G., \& Smith, P. (2014). Strategic human resource management: an international perspective. USA, NY: Sage.

Rhodes, S. R., \& Steers, R. M. (1981). Conventional vs. work-owned organizations, Human Relations, 34(12), 1013-1035. https://doi.org/10.1177/001872678103401201

Salas, E., Tannenbaum, S. I., Kraiger, K., \& Smith-Jentsch, K.A. (2012). The science of training and development in organizations: What matters in practice. Psychological science in the public interest, 13(2), 74-101. https://doi.org/10.1177/1529100612436661

Shannak, R., \& Almajali, D. (2010). Information technology investments: A literature review. Proceedings of the 14th IBIMA Conference on Global Business Transformation through Innovation and Knowledge Management: An Academic Perspective, Istanbul-Turkey, 23rd-24th June, pp.1356-1368.

Shannak, R., Al-Zu’bi, Z., Alshurideh, M., \& Altamony, H. (2012). A theoretical perspective on the relationship between knowledge management systems, customer knowledge management, and firm competitive advantage. European Journal of Social Sciences, 32, 520-532.

Shannak, R., \& Ali, M. (2012). Knowledge management strategy building: Literature review. European Scientific Journal, 8(15), 143-168.

Shannak, R., Obeidat, B., \& Masa'deh, R. (2012). Culture and the implementation process of strategic decisions in Jordan. Journal of Management Research, 4(4), 257-281. https://doi.org/10.5296/jmr.v4i4.2160

Shore, L. M., \& Tetrick, L. E. (1991). A construct validity study of the survey of perceived organizational support. Journal of applied psychology, 76(5), 637-649. https://doi.org/10.1037/0021-9010.76.5.637

Shore, L. M., \& Wayne, S. J. (1993). Commitment and employee behavior: comparison of affective commitment and continuance commitment with perceived organizational support. Journal of applied psychology, 78(5), 774-792. https://doi.org/10.1037/0021-9010.78.5.774

Solinger, O. N., Van Olffen, W., \& Roe, R. A. (2008). Beyond the three-component model of organizational commitment. Journal of applied psychology, 93(1), 70-83. https://doi.org/10.1037/0021-9010.93.1.70

Solomon, M. V., Bozga, R. E., \& Mateescu, M. A. (2013). Management of human resource: Past and present. In Proceedings of the Managerial Challenges of the Contemporary Society, Cluj-Napoca: Babes Bolyai University (pp. 185-190).

Taylor, S., (2014). Recruitment and selection. Strategic Human Resource Management: An International Perspective, 10(6), 139-14.

Vickers, G., McDonald, M., \& Grimes, J. (2014). A cross country comparison of best practices in recruitment and selection. Journal of Management and Marketing Research, 15(2), 1-9.

Wheelen, \& Hunger, J. D. (2012). Strategic management and business policy: toward global sustainability. Pearson/Prentice Hall, NJ: USA.

Vratskikh, I., Al-Lozi, M. \& Maqableh, M. (2016). The Impact of Emotional Intelligence on Job Performance via the Mediating Role of Job Satisfaction. International Journal of Business and Management, 11(2), 69-91. https://doi.org/10.5539/ijbm.v11n2p69

Wilkinson, A. Marchington, M., Dale, B. \& Graham, G. (1996). Quality and the human resource dimension. Management Research News, 19(6), 16-25. https://doi.org/10.1108/eb028474

Zhou, Y., Zhang, Y., \& Montoro-Sánchez, Á. (2011). Utilitarianism or romanticism: the effect of rewards on employees' innovative behaviour. International Journal of Manpower, 32(1), 81-98. https://doi.org/10.1108/01437721111121242 


\section{Appendix 1}

The constructs' measure, Mean, Standard Deviation and reliability

\begin{tabular}{|c|c|c|c|}
\hline Construct & Mean & $\begin{array}{l}\text { Standard } \\
\text { Deviation }\end{array}$ & $\begin{array}{l}\text { Cronbach } \\
\text { Alpha }\end{array}$ \\
\hline Recruitment and selection & 3.573 & 1.25 & 0.821 \\
\hline The recruitment and selection processes in this organization are impartial. & 3.553 & 1.22 & \\
\hline Favoritism is not evident in any of the recruitment decisions made here. & 3.520 & 1.16 & \\
\hline Interview panels are used during the recruitment and selection process in this organization. & 3.540 & 1.27 & \\
\hline This organization does not need to pay more attention to the way it recruits people. & 3.710 & 1.21 & \\
\hline $\begin{array}{l}\text { All appointments in this organization are based on merit (i.e. the best person for the job is } \\
\text { selected regardless of their personal characteristics). }\end{array}$ & 3.543 & 1.29 & \\
\hline Compensation and reward & 3.583 & 1.24 & 0.854 \\
\hline $\begin{array}{l}\text { Our company improves working conditions in order to recognize employee quality } \\
\text { improvement efforts. }\end{array}$ & 3.533 & 1.22 & \\
\hline $\begin{array}{l}\text { Our company has a salary promotion scheme for encouraging employee participation in } \\
\text { quality improvement. }\end{array}$ & 3.525 & 1.16 & \\
\hline The organization offers incentives to its employees related to their performance. & 3.541 & 1.27 & \\
\hline Employees' reward and penalties are clear. & 3.698 & 1.21 & \\
\hline Performance appraisal & 3.431 & 1.27 & 0.801 \\
\hline The company appraisal is a performance management system. & 3.383 & 1.24 & \\
\hline $\begin{array}{l}\text { Performance appraisal systems provide a framework to ensure all people are working to the } \\
\text { same objectives. }\end{array}$ & 3.430 & 1.35 & \\
\hline $\begin{array}{l}\text { Performance management systems develop the competencies of individuals either to further } \\
\text { individual ability or the competence of the organization. }\end{array}$ & 3.489 & 1.26 & \\
\hline Training and Development & 3.572 & 1.26 & 0.821 \\
\hline Employees receive training throughout their professional lives. & 3.593 & 1.32 & \\
\hline Employee training and development policies cover all the personnel in the firm. & 3.573 & 1.21 & \\
\hline Affective Commitment & 3.615 & 1.28 & 0.721 \\
\hline I would be very happy to spend the rest of my career with this organization. & 3.676 & 1.25 & \\
\hline I enjoy discussing about my organization with people outside it. & 3.593 & 1.32 & \\
\hline I really feel as if this organization's problems are my own. & 3.573 & 1.21 & \\
\hline I think that I could easily become as attached to another organization as I am to this one. & 3.353 & 1.28 & \\
\hline I do not feel like 'part of the family' at my organization. & 3.610 & 1.32 & \\
\hline I do not feel 'emotionally attached' to this organization. & 3.713 & 1.23 & \\
\hline This organization has a great deal of personal meaning for me. & 3.726 & 1.37 & \\
\hline I do not feel a 'strong' sense of belonging to my organization. & 3.677 & 1.25 & \\
\hline Continuance Commitment & 3.416 & 1.26 & 0.753 \\
\hline I am not afraid of what might happen if I quit my job without having another one lined up. & 3.427 & 1.21 & \\
\hline It would be very hard for me to leave my organization right now, even if I wanted to. & 3.563 & 1.24 & \\
\hline Too much in my life would be disrupted if I decided to leave my organization now. & 3.428 & 1.12 & \\
\hline It wouldn't be too costly for me to leave my organization now. & 3.383 & 1.24 & \\
\hline Right now, staying with my organization is a matter of necessity as much as desire. & 3.430 & 1.35 & \\
\hline I feel that I have very few options to consider leaving this organization. & 3.483 & 1.24 & \\
\hline $\begin{array}{l}\text { One of the few serious consequences of leaving this organization would be the scarcity of } \\
\text { available alternatives. }\end{array}$ & 3.190 & 1.36 & \\
\hline $\begin{array}{l}\text { One of the major reasons I continue to work for this organization is that leaving would } \\
\text { require considerable personal sacrifice-another organization may not match the overall } \\
\text { benefits I have here. }\end{array}$ & 3.425 & 1.19 & \\
\hline Normative Commitment & 3.599 & 1.20 & 0.792 \\
\hline I think that people these days move from company to company too often. & 3.699 & 1.21 & \\
\hline I do not believe that a person must always be loyal to his or her Organization. & 3.543 & 1.29 & \\
\hline Jumping from organization to organization does not seem at all unethical to me. & 3.707 & 1.10 & \\
\hline $\begin{array}{l}\text { One of the major reasons I continue to work in this organization is that I believe loyalty is } \\
\text { important and therefore feel a sense of moral obligation to Remain. }\end{array}$ & 3.553 & 1.22 & \\
\hline If I got another offer for a better job elsewhere I would not feel it was right to leave my & 3.520 & 1.16 & \\
\hline
\end{tabular}


organization

I was taught to believe in the value of remaining loyal to one organization. 3.533

1.27

Things were better in the days when people stayed in one organization for most of their 3.689

1.21

careers.

I do not think that to be a 'company man' or 'company woman' is sensible anymore.

3.543

1.29

\section{Copyrights}

Copyright for this article is retained by the author(s), with first publication rights granted to the journal.

This is an open-access article distributed under the terms and conditions of the Creative Commons Attribution license (http://creativecommons.org/licenses/by/4.0/). 